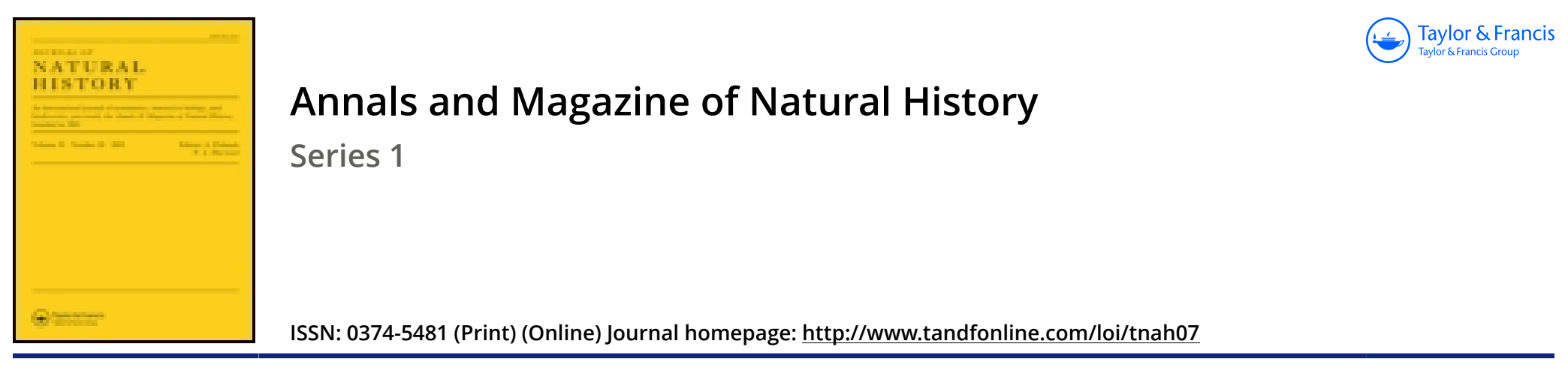

\title{
XXXIII.-Further observations on Ctenodus Labillardieri, in a Letter to the Rev. M. J. Berkeley, M.A. F.L.S.
}

\section{Montagne D.M. \& Rev. M.J. Berkeley M.A. F.L.S.}

To cite this article: C. Montagne D.M. \& Rev. M.J. Berkeley M.A. F.L.S. (1844) XXXIII.-Further observations on Ctenodus Labillardieri, in a Letter to the Rev. M. J. Berkeley, M.A. F.L.S., Annals and Magazine of Natural History, 14:91, 265-268, DOI: 10.1080/037454809495169

To link to this article: http://dx.doi.org/10.1080/037454809495169

曲 Published online: 23 Dec 2009.

Submit your article to this journal $\pi$

View related articles ¿ 
is very remarkable, M. de la Pylaie, who has analysed on the spot at Terre Neuve a great number of individuals of this same species, has never, more than myself, met with the other form of fructification. Nevertheless, Lyngbye has represented the basispermal fructification of this species, and Turner (Hist. Fuc. t.98) says even positively that in it he has seen the two sorts of filaments in the same conceptacle, and what is more, he represents them in such a way that one cannot fail to recognise them.

Such are the facts on which I found my opinion respecting the two modes of propagation in the Fucacea. I shall not conceal their insufficiency, for I freely acknowledge that they want the sanction of experience. Nevertheless, the subject appears to me to merit the attention of naturalists at a time when the Algæ have been made the subjects of so many important researches.

Some time ago M. M. Crouan (An. Sc. Nat. xii. p. 250) had spoken of the double fructification of Himanthalia, and more recently M. J. Agardh (Alg. Medit. et Adriat. p. 45) has agitated this same question, which had occupied my attention long ago, by expressing it under the form of a doubt. For example, he says, "Alter fructificationis forma in filis receptaculorum forsan adest, licet hoc experimentis direetis nondum probatum fuerit." The opinion of the celebrated Swedish phycologist, although stated with such reserve, appears to me to give some value to that which I have been attempting to sustain in this short notice. Whatever judgement may be passed on this, I shall persist in believing that there is in this matter something more than has been hitherto recognised, and that it is a subject of research which interests in a high degree the science of Algology.

XXXIII.-Further Observations on Ctenodus Labillardieri. By C. Montagne, D.M., in a Letter to the Rev. M. J. Berkeley, M.A., F.L.S.

\section{My dear Friend,}

You doubtless recollect that some time since you communicated to one of your Botanical Journals some observations which I had addressed to you in the course of our correspondence upon the fructification of the new genus Ctenodus. You will recollect too that I begged you to procure for me if possible a single fruit of the specimen figured in the excellent work of Turner ; for I could not persuade myself that so excellent an observer could have seen but one cell where I had seen twenty. It appeared then more than probable that the singular fructification which I have published, and which had also been observed by Mr. Harvey, was not the conceptacular form figured in the ' Historia Fucorum.' A recent com. Ann. \& Mag. N. Hist. Vol. xiv. 
munication from Mr. Harvey has proved the truth of my suspicion; and I take the earliest opportunity of informing you of it, that you may be so kind as to complete the communication relative to the very curious fructification of Fucus Labillardieri which you made on a former occasion. This fructification has the same external appearance as the other, and it is only on analysis that we find, that instead of a considerable number of cells it has but one, which opens by a pore at the summit. Among the admirable figures in Kützing's work, I do not find one capable of giving you an idea of it, or I should be content with merely citing it. I am going then to describe it as briefly as I can. From a central axillary placenta a tuft of branched articulated filaments arises in the form of a wheat-sheaf, whose coloured endochromes are rather longer than broad. Their tint is faint below, but as they approach the summit of the tuft, the colour becomes brighter and more purple. These are the last joints of the filaments in question, whose endochromes become the spores. They are in form oblong, resembling somewhat that of grape-stones. Measured by the micrometer their length is from one to two centièmes of a millimetre, and their breadth from the two-hundredth to the hundredth of a millimetre. They are of a beautiful purple and extremely numerous. As they are formed at the summit of the filaments and occupy the upper part of the cavity, we have the explanation of the imperfect figure of Turner, incomplete I mean in this sense, that the structure of his microscope did not allow him to see the rest of the fructifying apparatus. You see then that this fructification does not differ from that which we find in many other Floridee, and that without its remarkable tetrasporic fruit it would not form a distinct genus. You will moreover observe that I was not deceived in my anticipations, since chance has procured me the knowledge of the other mode of reproduction, of whose existence I felt sure from analogy. I received a day or two since a letter from M. Zanardini, a well-known phycologist of Venice, in answer to my communication relative to Ctenodus : you will see by the terms of his letter which I am going to translate, that the specimen which he possesses of Fucus Labillardieri has the conceptacular fruit. "I have examined attentively," he says, "your recent labours on the genus Ctenodrus. M. Diesing has given me a magnificent specimen of this Alga. I have subjected to a scrupulous examination many capsules, and I have felt vexed at not being able to observe the facts which your figures represent, either as regards the plurality of cells, or the centripetal direction of the organs of fructification." It is clear, since he could not observe them, that M. Zanardini had before him, not the form figured by me, but the conceptacular form illustrated by Turner. I do not like to let this opportunity escape of apprising you of 
another conceptacular fructification not less remarkable, and which must be very rare, since no one has hitherto described it. It is however that of one of our commonest Algæ; I mean Gelidium corneum. I think I showed you the analysis I had made on your late visit to Paris. In many dozens of individuals from different localities which exist in my herbarium, one only had conceptacular fruit; all the rest were either barren or had tetraspores. In his 'Algæ Mediterranei Maris,' M. J. Agardh excuses himself for not describing it ; because, he says, he has not got it at hand. This fructification however deserves to be known, and I am going to endeavour to give you an idea of it, which $I$ am sorry that I cannot accompany with a figure to make you understand it more easily.

The conceptacles of Gelidium corneum, which may be considered as the type of the genus, are developed in the ultimate pinnules which they terminate, so that the base of the pinnule forms a sort of peduncle, and the tip a mucro, which however is sometimes wanting. If by two parallel incisions made in the direction of the axis, one obtains a very thin slice of the centre of the conceptacle, and after carefully separating it from the lateral portions it is placed on the two plates of glass in Schiek's compressor, it appears under the microscope that the centre is traversed by a sort of columella. This, formed by the termination of the filaments which oceupy the centre of the fronds and of the branches, in a word by the medullary tissue, presents in this respect a sort of analogy with the organ of the same name in the capsule of mosses. From all points of its circumference there proceed numerous short branches which bear at their tips a little group of cells of the most delicate tissue, and of such extreme transparence that one can see them only by varying the intensity of light by means of the diaphragms of the instrument. The cells in question, at first almost spherical (at least there are some of this form mixed with the rest), become gradually oblongoclaviform as they increase. It is in their cavity that the spores are developed, but there are a great number which remain barren and consequently transparent. The spores, which are pyriform and of a deep purple, are innumerable, and placed horizontally round the central columella, from whence they radiate towards the walls of the cell, and to which they remain for a long while fixed by their more slender extremity. This disposition calls to mind the unilocular capsule of some Caryophyllea, traversed by a central placenta. I am only speaking as regards form. As the conceptacle has no natural aperture, at least in the individual before me, it appears probable that the spores are not dispersed till the decay of the plant.

I forgot to tell you, in order to complete my observations on 
Ctenodus, that in a letter lately received, Mr. Harvey tells me that at an advanced stage of growth, the receptacles of the individuals with tetrasporic fruit present a pore corresponding with each cell, by which the spores escape.

XXXIV.-Description of a Fossil Molar Tooth of a Mastodon discovered by Count Strzlecki in Australia. By Prof. Owen, F.R.S.

The large fossil femur, transmitted to England in 1842 by Lieut.Col. Sir T. L. Mitchell, Surveyor-General of Australia, from the alluvial or tertiary deposits of Darling Downs, and described in the 'Annals of Natural History' for January 1843, p. 8. fig. 1, gave the first indication of the former existence of a large Mastodontoid quadruped in Australia.

The portion of tooth described and figured in the same communication (p. 9. figs. 2 and 3), presenting characters very like those of the molars of both the Mastodon giganteus as well as of the Dinotherium, and being from the same stratum and locality as the femur with which it was transmitted, was regarded by me as having most probably belonged to the same animal ; and, on the authority of drawings subsequently received from Sir T. Mitchell, was referred to the genus Dinotherium*.

Having since received specimens of portions of lower jaws with teeth identical in structure with the fragment figured in my first communication to the 'Annals' (p. 9. figs. 2 and 3), I find that the reference of that portion of tooth to the genus Dinotherium was premature and erroneous. The extinct species to which it belonged does, indeed, combine molar teeth like those of the Dinotherium with two large incisive tusks in the lower jaw, but these tusks incline upwards instead of bending downwards, and are identical in form and structure with the tusk from one of the bone-caves of Wellington Valley, described by me in Sir T. Mitchell's ' Expeditions into the Interior of Australia,' vol. ii. 1838, p. 362. pl. 31. figs. 1 and 2 , as indicative of a new genus and species of gigantic marsupial animalt, to which I gave the name of Diprotodon australis.

It is not my present object to describe these most interesting additional fossils of the Diprotodon, or to enter into the question whether the great femur before alluded to belonged, like the fragment of tooth transmitted with it, to the Diprotodon, or to a

- Annals of Natural History, May 1843, p. 329. fig. 1.

+ See also my paper "On the Classification of Marsupialia," Zool. 'Trans. vol. ii. p. 332, in which the Diprotodon is placed with the Wombat in the family 'Phascolomyida.' 